\title{
Simultaneous enzymatic hydrolysis and anaerobic biodegradation of lipid-rich wastewater from poultry industry
}

\author{
Gisanara Dors • Adriano A. Mendes • \\ Ernandes B. Pereira $\cdot$ Heizir F. de Castro • \\ Agenor Furigo Jr.
}

Received: 15 June 2012/ Accepted: 28 December 2012/Published online: 10 January 2013

(C) The Author(s) 2013. This article is published with open access at Springerlink.com

\begin{abstract}
Simultaneous enzymatic hydrolysis and anaerobic biodegradation of lipid-rich wastewater from poultry industry with porcine pancreatic lipase at different concentrations (from 1.0 to $3.0 \mathrm{~g} \mathrm{~L}^{-1}$ ) were performed. The efficiency of the enzymatic pretreatment was measured by the Chemical Oxygen Demand (COD) removal and formation of methane. All samples pretreated with lipase showed a positive effect on the COD removal and formation of methane. After 30 days of anaerobic biodegradation the methane production varied from $569 \pm 95$ to $1,101 \pm 10 \mathrm{~mL}$ for crude wastewater and pretreated at $3.0 \mathrm{~g} \mathrm{~L}^{-1}$ enzyme, respectively. COD removal of wastewater supplemented at different enzyme concentrations was found to be threefold higher than crude wastewater. The use of lipases seems to be a promising alternative for treating lipid-rich wastewaters such as those from the poultry industry.
\end{abstract}

Keywords Lipase - Enzymatic hydrolysis - Anaerobic biodegradation - Poultry wastewater

G. Dors · A. Furigo Jr.

Federal University of Santa Catarina, Florianópolis, SC 88040-900, Brazil

A. A. Mendes $(\square)$

Federal University of São João del-Rei, Sete Lagoas,

MG 35701-970, Brazil

e-mail: mendes@ufsj.edu.br

E. B. Pereira

Federal University of Alfenas, Alfenas, MG 37130-000, Brazil

H. F. de Castro

Engineering School of Lorena, University of São Paulo, Lorena, SP 12602-810, Brazil

\section{Introduction}

Lipids are important components in wastewater that cause severe environmental pollution (Masse et al. 2001, 2003; Mendes et al. 2005, 2006, 2010; Demirel et al. 2005; Cammarota and Freire 2006; Rosa et al. 2009; Valladão et al. 2011). They can form an oil film on water surface, preventing the diffusion of oxygen from the air into water and leading to the death of aquatic life (Demirel et al. 2005; Cammarota and Freire 2006). Aggregates formed by oil droplets and other particles present in wastewater can also block water drainage lines. Treating wastewater rich in lipids in anaerobic digesters may cause operational problems including the flotation of granular biomass conducting to wash out, and severe toxicity of lipids against both methanogenic and acetogenic microorganisms (Vidal et al. 2000; Angelidaki and Sanders 2004).

To cope with these negative effects on water stream treatment, several strategies for removing lipid residues at the head of the plant have been proposed such as thermochemical, alkaline and enzymatic pretreatments (Sawayama et al. 1995; Masse et al. 2001; Mouneimne et al. 2003; Mendes et al. 2005, 2006, 2010; Cammarota and Freire 2006; Rosa et al. 2009; Valladão et al. 2011; Alexandre et al. 2011). Among these, the alternative of using specific enzymes (lipases) has recently gained attention because of stringent environmental regulations and a clean and friendly application of enzymes (Mendes et al. 2005, 2006, 2010; Cammarota and Freire 2006; Rosa et al. 2009; Valladão et al. 2011; Alexandre et al. 2011). Lipases (triacylglycerol ester acyl hydrolases EC 3.1.1.3) are enzymes that catalyze the hydrolysis of triacylglycerol to glycerol and long-chain fatty acids (LCFA) at the water-lipid interface (Mendes et al. 2012). These enzymes showed potential applications in hydrolyzing oil and fats in 
wastewater generated by dairy industries, slaughterhouses, edible oils, fat refineries and others (Mendes et al. 2006, 2010; Cammarota and Freire 2006; Rosa et al. 2009; Valladão et al. 2011; Alexandre et al. 2011). The application of lipases for wastewater pretreatment decreases the organic matter concentration, in terms of COD, color and suspended solids as lipids (Mendes et al. 2005, 2006, 2010; Cammarota and Freire 2006; Rosa et al. 2009; Valladão et al. 2011; Alexandre et al. 2011).

Previous works have shown that treating dairy wastewater with lipases from porcine pancreatic lipase (PPL) increased methane formation twofold in comparison to crude wastewater (Mendes et al. 2006, 2010). In this work, the effect of lipase addition in the anaerobic biodegradation of poultry wastewater was investigated by comparison with crude wastewater. To achieve this, different enzyme concentrations were used to perform the simultaneous anaerobic biodegradation and enzymatic hydrolysis of lipids from poultry wastewater employing commercially available lipase preparation from porcine pancreas. The selection of this lipase preparation was based on previous work carried out in our lab (Mendes et al. 2006). Moreover, it contains others hydrolytic enzymes as proteases and amylases that can be also important for the process since wastewaters from poultry industries contain lipids and protein compounds (Nuclear technical information).

\section{Materials and methods}

\section{Materials}

PPL was purchased from Nuclear (São Paulo, Brazil). The lipase is a crude preparation with an activity of 1,770 units $\mathrm{mg}^{-1}$ solid $\left(\mathrm{pH} 8.0\right.$ at $37^{\circ} \mathrm{C}$ ). The biochemical and kinetic properties of this lipase preparation are given elsewhere (Mendes et al. 2006). Crude wastewater from poultry industry (São José/SC, Brazil) was collected before the flotation tank and used in all experiments. The wastewater was stored in a freezer $\left(-4{ }^{\circ} \mathrm{C}\right)$ and analyzed in relation to the parameters of interest for the study. Acclimated anaerobic sludge from an up-flow anaerobic sludge blanket reactor (UASB) treating domestic sewage (3.27 g VSS L ${ }^{-1}$ and $4.27 \mathrm{~g} \mathrm{TSS} \mathrm{L}^{-1}$ ) was used as inoculum for the biodegradation assays. All other chemical reagents were of analytical grade.

Enzymatic hydrolysis and biodegradability tests

Enzymatic hydrolysis and anaerobic biodegradation assays were performed simultaneously in closed glass flasks with a total volume of $500 \mathrm{~mL}$, according to a methodology previously described (Mendes et al. 2006). A plastic tube connected the vial to a $500 \mathrm{~mL}$ inverted flask (Duran ${ }^{\circledR}$ flask) containing $\mathrm{NaOH}$ solution $\left(5.0 \mathrm{~g} \mathrm{~L}^{-1}\right)$ allowing methane production to be measured by the displacement of the liquid (see Fig. 1). Acclimated anaerobic sludge $(50 \mathrm{~mL})$ from a UASB reactor treating domestic sewage was transferred to the flasks containing crude wastewater $(250 \mathrm{~mL})$ and wastewater supplemented with PPL at different concentrations (from 1.0 to $3.0 \mathrm{~g} \mathrm{~L}^{-1}$ ). Then, the $\mathrm{pH}$ of the samples was adjusted to 8.0 with $\mathrm{NaOH} 1 \mathrm{~mol} \mathrm{~L}^{-1}$ solution. Before being closed, the bottles were flushed with nitrogen gas $\left(\mathrm{N}_{2}\right)$ to remove air in the flask head prior to incubation; the temperature was maintained at $35 \pm 1{ }^{\circ} \mathrm{C}$. The tests were carried out in duplicate for a minimum period of 30 days and gently stirred $(100 \mathrm{rpm})$. At end, the samples were centrifuged at $10,000 \times \mathrm{g}$ at room temperature during $30 \mathrm{~min}$ for further quantification of COD removal and free LCFA concentration. Control assays were also performed using acclimated anaerobic sludge containing $250 \mathrm{~mL}$ distilled water in the absence (Blank) and presence of PPL at different concentrations varying from 1.0 to $3.0 \mathrm{~g} \mathrm{~L}^{-1}$. The effect of wastewater enzymatic pretreatment on the efficiency of anaerobic biodegradation was determined by methane production and soluble COD removal. The soluble COD removal percentage $\left(\mathrm{COD}_{\text {removal }}\right)$ was calculated as follows:

$\mathrm{COD}_{\text {removal }}(\%)=\frac{\mathrm{COD}_{\text {initial }}-\mathrm{COD}_{\text {final }}}{\mathrm{COD}_{\text {initial }}} \times 100$

where $\mathrm{COD}_{\text {initial }}$ is the initial COD concentration of samples from the bioreactors and $\mathrm{COD}_{\text {final }}$ is the final soluble COD concentration of the samples after 30 days of anaerobic biodegradation at $35^{\circ} \mathrm{C}$. The $\mathrm{COD}$ values were expressed in $\mathrm{mg} \mathrm{L}^{-1}$.

Analytical methods

The $\mathrm{pH}$ value of the poultry wastewater was determined electrochemically using a Hanna Instruments model HI $2221 \mathrm{pH}$ meter (Hanna Instruments, Woonsocket, RI, USA). The concentration of free LCFA in the samples was determined by titration with $20 \mathrm{mmol} \mathrm{L}^{-1}$ sodium hydroxide solution in the presence of phenolphthalein as indicator (Mendes et al. 2006). Lipids concentration, total alkalinity, acidity, and COD were measured by the procedures described in the Standard Methods of Water and Wastewater Examination (APHA 1995). The fatty acid composition of the lipids present in poultry wastewater was identified by gas chromatography according to the method described by Metcalfe et al. (1966). 
Fig. 1 Scheme representative of the simultaneous enzymatic pre-treatment and anaerobic biodegradation of poultry wastewater 1 Thermostatic incubator, 2 bioreactor, 3 flask intermediary, 4 gas measured flask (Duran ${ }^{\circledR}$ flasks) and 5 collector flask

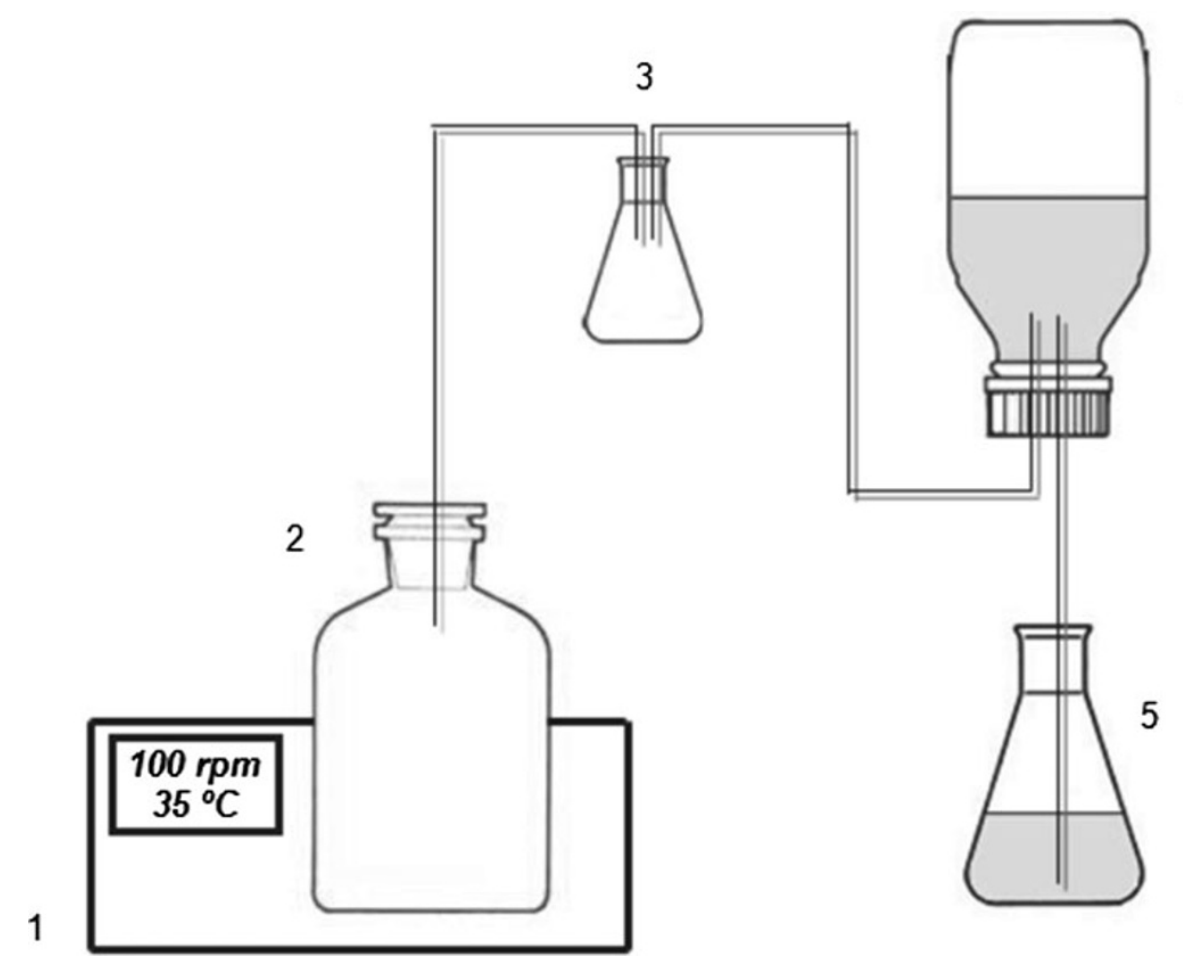

\section{Results and discussion}

Characterization of the poultry wastewater

The characteristics of the poultry wastewater used in this study were analyzed according to standard procedures and the values are given in Table 1 . The concentrations of lipids and COD from poultry wastewater were found to be 2,005 and 39,300 $\mathrm{mg} \mathrm{L}^{-1}$, respectively. These values were significantly higher than those reported by Bayar et al. (2011) who verified lipids and COD concentrations around 143 and $2,171 \mathrm{mg} \mathrm{L}^{-1}$, respectively. However, the level of total alkalinity was 18 -fold lower than poultry wastewater previously characterized by Debik and Coskun (2009). The wastewater presented $\mathrm{pH}$ at acidic region $(\mathrm{pH}$ 6.5), similar to the results previously elsewhere (Debik and Coskun 2009; Bayar et al. 2011). Concerning the fatty acids distribution, the crude wastewater contained high concentration of palmitic acid $(46.5 \mathrm{wt} \%)$, followed by oleic acid (29.5 wt\%), stearic (11.5 wt\%), palmitoleic (2.90 wt\%) and linoleic ( $>2 \mathrm{wt} \%$ ), in agreement to the results previously reported (Quéméneur and Marty 1994).

Simultaneous enzymatic treatment and biodegradability tests

Figure 2 shows the accumulated methane production for anaerobic sludge (Blank), crude and supplemented poultry wastewater with PPL as well as the kinetic profiles attained in batch reactors. There was an improvement in the efficiency of the anaerobic biodegradability for the wastewater containing the enzyme. The profiles of the methane production followed a first-order kinetic and the angular coefficients of the assays carried out with PPL at different concentrations were, nearly, four- and ten-fold higher than that those determined for crude wastewater and anaerobic sludge (Blank), as shown in Fig. 2a, b). Interestingly, high correlation coefficients $\left(R^{2}\right)$ were observed for both models. Simultaneous hydrolysis enzymatic and anaerobic biodegradation performed at low enzyme loading $\left(1.0 \mathrm{~g} \mathrm{~L}^{-1}\right)$ was enough to promote the liquefaction of lipid droplets. This liquefaction of insoluble biodegradable compounds such as lipids is generally the rate-limiting step in the anaerobic biodegradation processes (Sayed et al. 1988; Cammarota and Freire 2006). Hence, the use of PPL increased the hydrolysis of lipids and the bioavailability of their byproducts such as long-chain fatty acids and glycerol, which are more easily assimilated by anaerobic biomass. These findings are in agreement with other results (Mendes et al. 2006, 2010; Rosa et al. 2009; Valladão et al. 2011). After $100 \mathrm{~h}$ of anaerobic biodegradation, a slight reduction on the methane formation rate was observed for all samples supplemented with PPL (see angular coefficients values in Fig. 2c-e. This slight decrease could be explained by the reduction of the organic matter concentration and possible accumulation of volatile organic acids, such as acetic and propionic acids that lead to the inhibition of biological activity of anaerobic biomass (Vidal et al. 2000). 
Table 1 Characterization of poultry wastewater used in this study

\begin{tabular}{|c|c|}
\hline Parameter & Result \\
\hline $\mathrm{pH}$ & 6.50 \\
\hline Acidity $\left(\mathrm{mg} \mathrm{KOH} \mathrm{g}^{-1}\right)$ & 40.4 \\
\hline Total alkalinity $\left(\mathrm{mg} \mathrm{CaCO}_{3} \mathrm{~L}^{-1}\right)$ & 73.0 \\
\hline Total solid $\left(\mathrm{mg} \mathrm{L}^{-1}\right)$ & 8,390 \\
\hline Initial COD $\left(\mathrm{mg} \mathrm{L}^{-1}\right)$ & 39,300 \\
\hline Lipids $\left(\mathrm{mg} \mathrm{L}^{-1}\right)$ & 2,005 \\
\hline Specific mass $\left(\mathrm{g} \mathrm{mL}^{-1}\right)$ & 1.01 \\
\hline Free LCFA $\left(\mathrm{mg} \mathrm{g}^{-1}\right)$ & 5.30 \\
\hline Palmitic acid (wt\%) & 46.5 \\
\hline Palmitoleic acid (wt\%) & 2.90 \\
\hline Stearic acid (wt\%) & 11.5 \\
\hline Oleic acid (wt\%) & 29.5 \\
\hline Linoleic acid (wt\%) & 1.99 \\
\hline
\end{tabular}

The final methane volume produced after 30 days of anaerobic biodegradation of crude and wastewater supplemented with PPL at different concentrations are summarized in Table 2. Anaerobic sludge (Blank) showed endogenous methane production around $262 \mathrm{~mL}$. The supplementation of PPL is expected to increase the methane production because this lipase preparation contains in its composition other enzymes and preserving agents such as sugars and bile salts (Mendes et al. 2012). However, blank assays containing anaerobic sludge supplemented with PPL at different concentrations presented negligible influence on the accumulated volumetric methane production and COD removal, around $5 \%$ higher than Blank. As expected, all assays supplemented with lipase rendered higher accumulated volumetric methane production than crude wastewater. The methane production from crude wastewater was found to be $569 \pm 95 \mathrm{~mL}$, twice higher than Blank assay. At a low enzyme concentration $\left(1.0 \mathrm{~g} \mathrm{~L}^{-1}\right)$, the maximum methane volume produced was found to be $793 \pm 55 \mathrm{~mL}$, slightly lower than the assay supplemented with $2.0 \mathrm{~g} \mathrm{~L}^{-1}(892 \pm 22 \mathrm{~mL})$. Anaerobic biodegradation carried out using $3.0 \mathrm{~g} \mathrm{~L}^{-1}$ of lipase produced the highest methane volume after 30 days of incubation $(1,101 \pm 10 \mathrm{~mL})$, ca. twofold higher than crude wastewater. Biomass flotation was observed for crude wastewater, which could be attributed to the presence of lipids. The adsorption of lipids to the surface of anaerobic biomass may limit transport of soluble substrates to the biomass and cause reduction on the methane production and, consequently, biomass flotation (Mendes et al. 2006; Cirne et al. 2007; Rosa et al. 2009; Valladão et al. 2011). At higher concentrations, they can solubilize the membrane to such an extent that various membrane proteins or larger sections of the lipid bilayer are released (Valladão et al. 2011). The increase in the formation of methane for lipid-rich wastewater from food processing industries treated with PPL and other lipase preparations has been also broadly reported for dairy wastewater (Mendes et al. 2006, 2010; Rosa et al. 2009; Valladão et al. 2011).

It is well known that free LCFA at low concentrations are also responsible for the inhibition of anaerobic biomass (Perle et al. 1995; Angelidaki and Sanders 2004). Similar to the lipids, these compounds also adsorb on the cell membrane of the anaerobic microorganisms (Angelidaki and Sanders 2004). In this set of experiments, the concentration of free LCFA after anaerobic biodegradability was measured as displays in Table 2. Crude wastewater showed $5.30 \mathrm{mg}$ of free LCFA per gram of wastewater (see Table 1). However, after anaerobic biodegradation for the samples supplemented with PPL at different concentrations, similar free LCFA concentration was found (Table 2), which could be attributed to the non-converted long-chain fatty acids and/or intermediate carboxylic acids produced by $\beta$-oxidation reactions during anaerobic biodegradation (Salminen and Rintala 2002; Cammarota and Freire 2006; Cirne et al. 2007). Lalman and Bagley (2001) reported that palmitic acid is the main product detected from oleic acid, second main LCFA found in poultry wastewater (29.5 wt\%-see Table 1), followed by stearic acid. According to the authors, the production of these intermediates LCFA from oleic acid is thermodynamically favorable. Their strong inhibition into anaerobic biodegradability is widely reported, although free LCFA from poultry wastewater did not inhibit methane production and COD removal during anaerobic biodegradation of poultry wastewater in the absence and presence of PPL at different concentrations. This behavior can be explained through the use of an acclimated biomass that improved the assimilation of the organic matter contained in the wastewater. The use of acclimated biomass assimilates more easily organic matter such as proteins and lipids than no acclimated biomass (Perle et al. 1995). For anaerobic sludge, the initial free LCFA concentration was found to be $6.1 \pm 1.2$ $\mathrm{mg} \mathrm{g}^{-1}$. However, it was observed an increase of free LCFA concentration by a factor twofold after 30 days of incubation $\left(10.1 \pm 0.7 \mathrm{mg} \mathrm{g}^{-1}\right)$. Perhaps, these free LCFA could be released from anaerobic biodegradation of lipids from microbial biomass, e.g. anaerobic sludge from UASB reactors contains in its composition $5 \%$ dry weight lipids (Alexandre et al. 2011).

Concerning the removal of organic matter in terms of COD, all assays performed with the supplementation of PPL resulted in higher COD removal than crude wastewater, including the anaerobic sludge (Table 2). Under the experimental conditions the COD removal for anaerobic sludge was around $38 \%$. The addition of crude wastewater to anaerobic sludge reduced COD removal percentage after 30 days of anaerobic biodegradation for $31.0 \pm 3.2 \%$. 
Fig. 2 Accumulated volumetric methane production for anaerobic sludge a crude wastewater $\mathbf{b}$ and pre-treated poultry wastewater with $1.0 \mathrm{c}$, $2.0 \mathrm{~d}$ and $3.0 \mathrm{~g} \mathrm{~L}^{-1}$ PPL e after 30 days of anaerobic biodegradation $\left(35^{\circ} \mathrm{C}\right.$, agitation $100 \mathrm{rpm})$
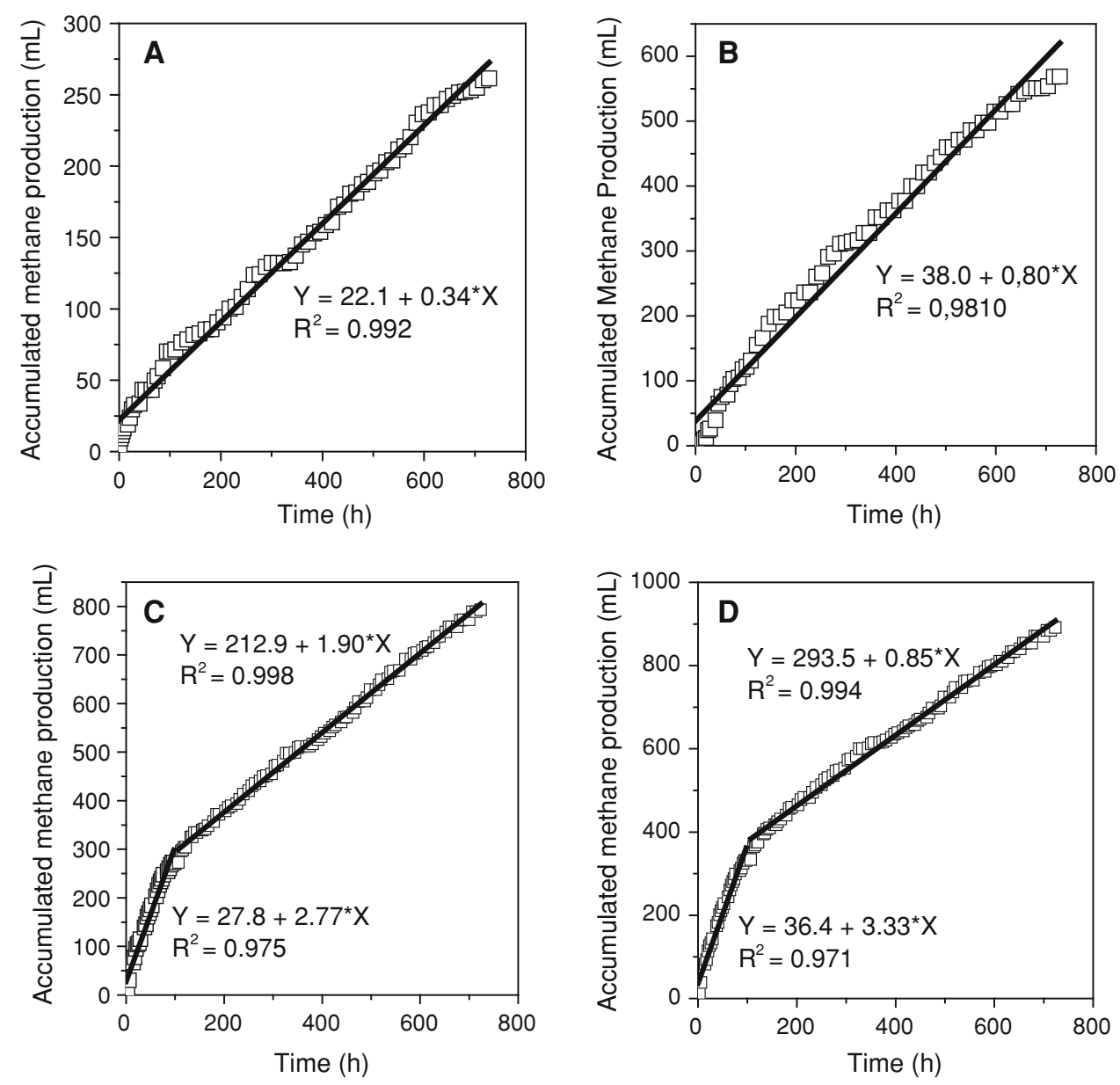

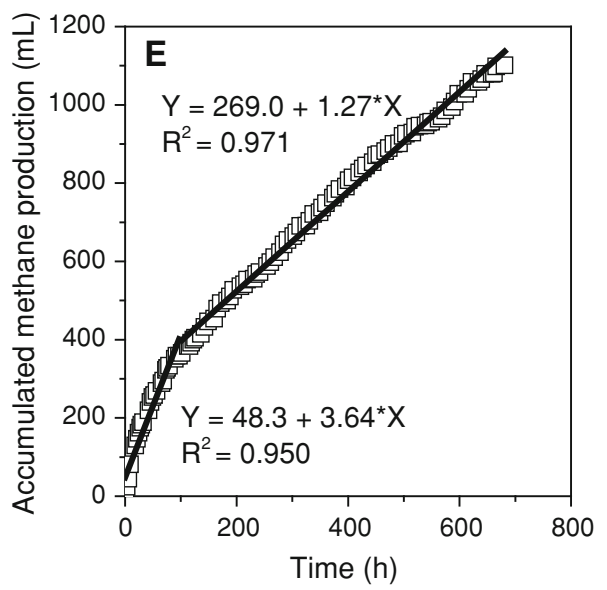

Based on these results, this reduction may be attributed to the adsorption of free LCFA and lipids from crude wastewater onto the cell wall/membrane of the anaerobic sludge. However, for samples containing PPL the levels of organic matter removal were threefold higher $(\sim 88 \%)$, with a maximum value attained for sample supplemented with $3.0 \mathrm{~g} \mathrm{~L}^{-1}$ of lipase $(92.0 \pm 2.7 \%)$. Although high enzyme concentration gave the highest COD removal, low enzyme concentrations (1.0-2.0 $\left.\mathrm{g} \mathrm{L}^{-1}\right)$ also gave similar results in terms of COD removal $(\sim 88 \%)$. The results show that the supplementation of lipases at low concentration was enough to improve the assimilation of organic compounds through anaerobic biomass, in agreement to the results previously reported in the literature (Mendes et al. 2006, 2010; Rosa et al. 2009; Valladão et al. 2011).

The application of PPL to treat lipid-rich wastewater from food industries has been well documented. Slaughterhouse wastewater, containing between 2.5 and $3.0 \mathrm{~g} \mathrm{~L}^{-1}$ 
Table 2 Composition of the wastewater biodegraded in batch reactors supplemented with samples containing different PPL concentrations

\begin{tabular}{lllr}
\hline Assays & Free LCFA $\left(\mathrm{mg} \mathrm{g}^{-1}\right)$ & COD removal $(\%)$ & Methane $(\mathrm{mL})$ \\
\hline Blank & $10.1 \pm 0.72$ & $38.0 \pm 0.4$ & $262 \pm 27$ \\
Crude wastewater & $6.10 \pm 0.95$ & $31.6 \pm 1.7$ & $569 \pm 95$ \\
PPL & & & $793 \pm 55$ \\
$1.0 \mathrm{~g} \mathrm{~L}^{-1}$ & $4.50 \pm 0.42$ & $88.1 \pm 3.4$ & $892 \pm 22$ \\
$2.0 \mathrm{~g} \mathrm{~L}^{-1}$ & $6.82 \pm 0.95$ & $88.2 \pm 3.1$ & $1,101 \pm 10$ \\
$3.0 \mathrm{~g} \mathrm{~L}^{-1}$ & $4.28 \pm 0.13$ & $92.0 \pm 2.7$ & \\
\hline
\end{tabular}

Blank: assay conducted by incubating anaerobic sludge at experimental conditions assay $\left(35^{\circ} \mathrm{C}\right.$, agitation $100 \mathrm{rpm}, 30$ days)

of lipids, was pretreated with PPL during $4 \mathrm{~h}$ at room temperature (Masse et al. 2001). Pretreatment with PPL reduced $60 \%$ average particle size and increased the free long-chain fatty acid concentration, indicating some solubilization of the pork fat particles in the slaughterhouse wastewater. In another study, Masse et al. (2003) also pretreated slaughterhouse wastewater containing pork fat particles with selected PPL (PL-250) at $25{ }^{\circ} \mathrm{C}$ for $5.5 \mathrm{~h}$. The effect of the enzymatic pretreatment was evaluated by biodegradability assays in anaerobic sequencing batch reactors operated at $25^{\circ} \mathrm{C}$. Enzymatic pre-treatment resulted in a decrease of digestion time about $5 \%$ and a high reduction $(80 \%)$ of fat and LCFA concentration, compared to crude wastewater. PPL was tested in the hydrolysis of lipids from dairy wastewater at $37{ }^{\circ} \mathrm{C}$ for different incubation time (4-24 h) with $5.0 \mathrm{~g} \mathrm{~L}^{-1}$ of lipase preparation (Mendes et al. 2006). The pretreatment was optimized for $12 \mathrm{~h}$ hydrolysis time, enabling high-methane formation and COD and color removal. Promising results in comparison to the methane formation and COD removal were also found when hydrolysis and biodegradation steps were carried out, simultaneously. In a subsequent study, enzymatic pretreatment of dairy wastewater was also carried out by offering different enzyme concentrations (0.5-5.0 $\left.\mathrm{g} \mathrm{L}^{-1}\right)$, followed by anaerobic biodegradation assays (Mendes et al. 2010). The results showed that the hydrolysis and anaerobic biodegradation could be carried out simultaneously, preferentially using low enzyme concentration $\left(0.05 \mathrm{~g} \mathrm{~L}^{-1}\right)$. Under these conditions, COD and color removal was, respectively, two and sixfold higher than crude wastewater in agreement with the results obtained in the present work.

\section{Conclusions}

In this work, a commercially available lipase preparation from porcine pancreas was used for decreasing lipids and organic matter contents in poultry wastewater. The biodegradation tests carried out with the supplementation of lipases, independent of the lipase concentration, increased levels of methane production and COD removal in relation to crude wastewater assay. Promising results were obtained for simultaneous enzymatic hydrolysis and anaerobic biodegradation performed at low enzyme concentration (1.0 $\left.\mathrm{g} \mathrm{L}^{-1}\right)$. The supplementation of lipase during the anaerobic biodegradation of lipid-rich wastewaters from food industries represents an attractive solution to solve problems of low biodegradation of these.

Acknowledgments The authors gratefully acknowledge the financial assistance from CAPES, CNPq and FAPESP, Brazil.

Open Access This article is distributed under the terms of the Creative Commons Attribution License which permits any use, distribution, and reproduction in any medium, provided the original author(s) and the source are credited.

\section{References}

Alexandre VMF, Valente AM, Cammarota MC, Freire DMG (2011) Performance of anaerobic bioreactor treating fish-processing plant wastewater pre-hydrolyzed with a solid enzyme pool. Renew Energy 36:3439-3444

Angelidaki I, Sanders W (2004) Assessment of the anaerobic biodegradability of macropollutants. Rev Environ Sci Biotechnol 3:117-129

APHA AWWA WPCF (1995) Standard methods for the examination of water and wastewater, 19th edn. Published jointly by American Public Health Association, American Water Works Association and Water Environment Federation. Washington, USA

Bayar S, Yildiz YS, Yilmaz AE, Irdemez S (2011) The effect of stirring speed and current density on removal efficiency of poultry slaughterhouse wastewater by electrocoagulation method. Desalination 280:103-107

Cammarota MC, Freire DMG (2006) A review on hydrolytic enzymes in the treatment of wastewater with high oil and grease content. Bioresour Technol 97:2195-2210

Cirne DG, Paloumet X, Bjornsson L, Alves MM, Mattiasson B (2007) Anaerobic digestion of lipid-rich waste-effects of lipid concentration. Renew Energy 32:965-975

Debik E, Coskun T (2009) Use of the Static Granular Bed Reactor (SGBR) with anaerobic sludge to treat poultry slaughterhouse wastewater and kinetic modeling. Bioresour Technol 100: 2777-2782

Demirel B, Yenigun O, Onaya TT (2005) Anaerobic treatment of dairy wastewaters: a review. Process Biochem 40:2583-2595 
Lalman JA, Bagley DM (2001) Anaerobic degradation and methanogenic inhibitory effects of oleic and stearic acids. Water Res 35:2975-2983

Masse L, Kennedy KJ, Chou S (2001) Testing of alkaline and enzymatic hydrolysis pretreatments for fat particles in slaughterhouse wastewater. Bioresour Technol 77:145-155

Masse L, Massé DI, Kenned KJ (2003) Effect of hydrolysis pretreatment on fat degradation during anaerobic digestion of slaughterhouse wastewater. Process Biochem 38:1365-1372

Mendes AA, Castro HF, Pereira EB, Furigo A Jr (2005) Aplicação de lipases no tratamento de águas residuárias com elevados teores de lipídeos. Quím Nova 28:296-305

Mendes AA, Pereira EB, Castro HF (2006) Effect of the enzymatic hydrolysis pretreatment of lipids-rich wastewater on the anaerobic biodigestion. Biochem Eng J 32:185-190

Mendes AA, Pereira EB, Furigo A Jr, Castro HF (2010) Anaerobic biodegradability of dairy wastewater pretreated with porcine pancreas lipase. Braz Arch Biol Technol 53:1279-1284

Mendes AA, Oliveira PC, Castro HF (2012) Properties and biotechnological applications of porcine pancreatic lipase. J Mol Catal B Enzym 78:119-134

Metcalfe LD, Schmitz AA, Pelka JR (1966) Rapid preparation of fatty acid esters from lipids for gas chromatographic analysis. Anal Chem 38:514-515

Mouneimne AH, Carrere H, Bernet N, Delgenes JP (2003) Effect of saponification on the anaerobic digestion of solid fatty residues. Bioresour Technol 90:89-94
Perle M, Kimchie S, Shelef G (1995) Some biochemical aspects of the anaerobic degradation of dairy wastewater. Water Res 29:1549-1554

Quéméneur M, Marty Y (1994) Fatty acids and sterols in domestic wastewater. Water Res 28:1217-1226

Rosa DR, Duarte ICS, Saavedra NK, Varesche MB, Zaiat M, Cammarota MC, Freire DMG (2009) Performance and molecular evaluation of an anaerobic system with suspended biomass for treating wastewater with high fat content after enzymatic hydrolysis. Bioresour Technol 100:6170-6176

Salminen E, Rintala J (2002) Anaerobic digestion of organic solid poultry slaughterhouse waste-a review. Bioresour Technol 83:13-26

Sawayama S, Inoue S, Yagishita T, Ogi T, Yokoyama SY (1995) Thermochemical liquidization anaerobic treatment of dewatered sewage sludge. J Ferment Bioeng 79:300-302

Sayed S, van der Zanden J, Wijffels R, Lettinga G (1988) Anaerobic degradation of the fractions of slaughterhouse wastewater. Biol Wastes 23:117-142

Valladão ABG, Torres AG, Freire DMG, Cammarotta MC (2011) Profiles of fatty acids and triacylglycerols and their influence on the anaerobic biodegradability of effluents from poultry slaughterhouse. Bioresour Technol 102:7043-7050

Vidal G, Carvalho A, Méndez R, Lema JM (2000) Influence of the content in fats and proteins on the anaerobic biodegradability of dairy wastewater. Bioresour Technol 74:231-239 